\title{
RECENT RESEARCHES IN AMERICAN ARCHÆOLOGY
}

\begin{abstract}
MONG numerous evidences of increased interest $A$ in the United States of America in the antiquities of the continent and the origin, character and cultures of its earlier inhabitants is the fact that research in branches of study bearing upon such problems is no longer confined mainly to the more influential and populous intellectual centres, with their widely known and strongly supported universities, museums and other learned bodies. Local research, and even investigations implicating extended ramifications, are now appearing with regularity in the departmental studies of universities and academic institutions in the outlying and remoter States. Financial support, however, at least so far as concerns investigation in the field, is not always readily to be obtained, and various economies have to be practised. If these affect publication, as indeed frequently happens, results of importance may be overlooked, especially in Great Britain, where, unfortunately, it is sometimes difficult for archæologists to keep fully abreast with the progress of such research in America. Owing, however, to the financial limitations to which reference has been made, an index to activity in research, naturally not in archæology only, which alone is under consideration here, is afforded by the reports of bodies administering the various funds, to which scientific research in America is in the fortunate position of being able to look for support. Among such bodies, the American Philosophical Society takes a prominent place, owing to the value of the funds under its control, while the accounts of the researches it subsidizes which appear in the Year Book*, brief as they are, are a valuable guide to the trend of scientific investigation in widely extended fields throughout the academic world of the United States.
\end{abstract}

From this point of view, the following notes on recent archæological investigations, extracted from reports in the Year Book, will be of interest.

The discovery of characteristic stone artefacts attesting the existence of an early and primitive hunting people, who from the association of their relics, it is evident, were contemporary with a fauna pleistocene in character and now extinct-a people to whom the distinguishing name of Folsom man is assigned-has naturally given rise to inquiry as to how and by which route this culture and other cultures, apparently even earlier in time, reached the south-western States, the region of their discovery. The hypothesis that their penetration of the southwest was from the north, and took place in the Pleistocene age, by way of an ice-free corridor, has naturally stimulated investigation with the view of finding traces of the distinctive eulture of Folsom man in the more northerly regions of the continent. The search has not been without result, notably in the work of Dr. F. H. H. Roberts in Canada. An investigation on similar lines was undertaken by Wesley $\mathrm{L}$. Bliss, of the University of New Mexico, by whom an archæological and geological reconnaissance has been carried out in Alberta, the Mackenzie Valley, and on the Upper Yukon, with the financial assistance of the American Philosophical Society.

- The American Philosophical Societv. Year Book, 1938. Pp. 407. Philadelphia : American Philosophical Society, 1939.)
In the preliminary report the purpose of the investigation is stated to be "to tie in, if possible, early cultural and culture complexes in relation to glacial chronology". It followed on investigations already earried out in 1937 with the co-operation of the University of Alberta in which Yuma points, belonging to a south-western culture related to the Folsom culture, were located in eastern Alberta, and cultural affinities and contacts were demonstrated with British Columbia and Wyoming or the west coast, while abalone shell-pendants indicated connexions with the Californian coast. In the following season, geological investigations showed that all the area covered by the expedition along the Sikanni, Nelson and Liard Rivers of the Mackenzie River basin had been glaciated by Keewatin ice. Evidence of cave occupation by man was found near Blue Fish Lake, north of the Nahanni Butte, where ash layers overlay the blue clay deposited during glaciation, while information was obtained of smoke-darkened walls in two others. Search for evidence of man below the clay, which would prove human priority to the Keewatin advance of the ice in this region, is obviously desirable. The existence of an ice-free corridor from Bering Straits eastward to the Mackenzie delta was inferred from the absence of any evidence of glaciation in the valley of the Little Bell River, a tributary of the Yukon. Near Neon Lake, at the top of the pass, two terraces above the lake yielded artefacts com. parable to the Pleistocene Lake Mohave artefacts of California and closely resembling those from the lowest cultural stratum of Borax Lake, California, which antedate the Folsom culture.

On returning to Alberta, field work was resumed, and four Yuma sites were found near Cereal, and two Folsom sites examined in western Saskatchewan. Of these, one near Mortlach is situated on the Altamont moraine and definitely dates Folsom as post-Wisconsin. An isolated flaked microlithic point from eastern Alberta is identical with points from the campus of the University of Alberta and also with those of the dune dwellers of Gobi in Central Asia.

Geographical conditions show that the great river basins of the north-west were more probable routes of migration from Asia than the rugged Alaskan and British Columbian coasts. Mapping of the Illinoian and Wisconsin moraines indicates an open corridor between the mountains and the continental glaciers in these periods.

Prior to this reconnaissance, nothing was known archæologically of the regions covered.

Recent archæological surveys of the south-western United States have been directed to the classification of the cultures found on occupation sites. Of the four basic cultures recognized, little is known by excavation of the Patayan culture, which centres in the Colorado River valley below Boulder Dam. In fact, north-western Arizona, to which this culture belongs, has been a blank place on the archæological map.

In the summer of 1938, an expedition of the Museum of Northern Arizona under Lyndon $L$. Hargrave, field director of the Museum, with the assistance of a generous grant from the Penrose 
Fund, made an intensive study of sub-cultures of the Patayan culture, excavating a site seven miles north of Williams, Arizona, which consisted of a large masonry fort and seventeen earth lodge sites. A preliminary conclusion, pending further analyses, establishes the existence of the Cohonina Branch of the Patayan culture, differing essentially from the Hohokam of the south and the Pueblo to the east. A relationship to the people of the Colorado to the west is suggested.

The Cohonina lived a semi-sedentary life, part agricultural, part food-gathering. Their homes were surface structures built of perishable material, earth lodges, of which the detailed architecture is difficult to trace. Much charcoal was collected, which, however, has as yet yielded no dendrochronological evidence. Ceramic types date occupation at about A.D. 700 and A.D. 1100, the fort with its massive masonry belonging to the later period of occupation. A special projectile point was used to which the name "Cohonina point" has been given. Few ornaments were used, none of shell. The pottery belongs to the San Francisco mountain gray ware; and from its distribution it is possible to fix the extension of the Cohonina Branch-the area between the Little Colorado River on the east and the escarpment of the plateau on the west, and from the Grand Canyon on the north to the San Francisco volcanic field in the south.

An investigation of primitive Indian agriculture in the south-west by Edward F. Castetter, of the University of New Mexico, throws light on the crops grown anciently in this region. A preliminary survey was made of the technique, crops and implements among Mohave, Yuma, Cocopa, Maricopa, Papago, Pima, and a number of Pueblo groups. The ancient crops were maize, beans, pumpkins, cotton, tobacco and gourd. In addition, the Colorado River tribes sowed several species of grasses. The Pueblo peoples had a much greater variety of corn and beans than the peoples of the Gila and Colorado Rivers, who had only four-yellow, blue, white and speckled, all corn of the flour type. The pumpkins were Cucurbita moschata. It was found that agriculture could not be investigated adequately without knowledge of ritual, the two being inseparable ; but it was difficult to obtain information owing to the secrecy of the Indians, especially the Pueblo, on such matters.

\section{BIOLOGY AND SYSTEMATICS OF THE SARGASSUM WEED}

$\mathrm{M}^{\mathrm{A}}$ ATERIAL for research on the floating Sargassum vegetation of the western North Atlantic was collected in connexion with a series of hydrographic cruises to the central American seas on the research ship Atlantis, sponsored jointly by the Woods Hole Oceanographic Institution and by Yale University (under the auspices of the Bingham Oceanographic Foundation), a special surface net being used which was designed to gather floating weeds from the sea surface on a quantitative basis, and the results of the researches have now been published*.

This net has been in actual operation on the surface of the Sargasso Sea and of the central American seas for a total cumulative towing length of nearly 7,000 nautical miles, and as a result of this towing more than 4,700 pounds of pelagic weeds have been sorted and weighed on board. Experimental evidence shows that these weeds do not occur in any quantity at any significant distance below the surface.

In the taxonomic discussion a key is given for the identification of the main types of floating Sargassum weed, illustrated by a number of silhouettes. The author concludes that the fixed, more or less distinct, external forms in which the truly pelagie weeds occur represent only phenotypic variations of not more than two separate species, S. natans and S. fluitans. Even the distinctness of these two species, although probable, is not established entirely without doubt.

The quantitative estimates show that floating weed is scarce in the Caribbean and Cayman Seas and practically absent from the entire southern half of the Caribbean itself, whilst in the north-western region of the Gulf of Mexico a secondary accumulation

* "Quantitative Observations on the Pelagic Sargassum Vegetation of the Western North Atlantic. With Preliminary Discussion of Morphology and Relationships". By Albert Eide Parr. Bull. Bingham Oceanographic Collection, Peabody Museum of Natural History, Yale University, 6, Art. 7. Dec. 1939. of apparently deteriorating weeds in considerable abundance was observed over a wide area. The chief region for thriving pelagic weeds was entirely outside the central American seas in that part of the North Atlantic designated as the Sargasso Sea.

The distribution, as shown in these results, confirms the previous hydrographic conclusions, that the failure of the drifting flora to penetrate northward across the Caribbean agrees with the assumption that the Caribbean surface water is mainly derived from the south-east via the north equatorial current and not from the Sargasso Sea itself. The accumulation of floating weed in the north-western part of the Gulf of Mexico must be interpreted as a result of pure wind drift, due to prevailing easterly winds moving the weeds in relation to the water; this accumulation could scarcely take place in the presence of a significant tendency to outward movement of the surface water towards the Straits of Florida.

Up to the present time, no benthonic fixed stage is known of the two species S. natans and S. fuitans, and it has been a controversial subject as to whether these weeds grow vegetatively to any great extent in the floating state. Recent authorities increasingly favour the theory that such growth does take place, and the present work shows conclusively that these weeds grow and prosper for years without any sexual reproduction; and further, there can be no conceivable source and process of annual renewal of pelagic Sargassum vegetation from benthonic flora which could possibly maintain the floating vegetation in its observed abundance with an average duration of the pelagic state of the individual plants to be reckoned in less than decades. One fertile plant attached to a drifting piece of wood was obtained which was otherwise indistinguishable from sterile representatives of the pelagic $S$. fluitans, the only 